\title{
Application of Tracking Letter Disposition at State Polytechnic of Sriwijaya Based on Android Webview
}

\author{
Indra Satriadi ${ }^{1, *}$ Sony Oktapriandi ${ }^{1}$ Hetty Meileni ${ }^{1}$ Desy Aprianty ${ }^{1}$ \\ ${ }^{1}$ State Polytechnic of Sriwijaya \\ *Corresponding author. Email:abididit72@gmail.com
}

\begin{abstract}
Letter disposition is an integral part of the operational activities of an organization. One of the efforts to increase the effectiveness of the letter communication is by using Information and Communication Technology (ICT). This study focuses on making applications that make it easier for users to monitor the disposition of letters from and to leaders in the Sriwijaya State Polytechnic environment. The research stage was started by starting the research by determining the background, problems, scope, and focus of the research discussion. Data collection was carried out through observation, interview and document study. The next stage is to conduct a system analysis consisting of Problem Analysis, Current System Analysis and Proposed System Analysis. The design uses a structured method using context diagrams, Data Flow Diagrams (DFD), Entity Relationship Diagrams (ERD). System implementation with the PHP programming language and MYSQL database. The final result of this research is a mail tracking application based on Android Webview.
\end{abstract}

Keywords: Application, Letter Disposition, Android Webview

\section{INTRODUCTION}

Information technology has an impact on accelerating data processing in all aspects of life. Utilization of Information Technology is also used in the administrative process of an institution in an effort to increase efficiency and speed up the policy making process. One of the implementations of the use of Information Technology in office administration is the process of disposing of correspondence. Letter disposition becomes an optional activity after the distribution of letters, where the steps for distributing letters are delivering letters to the intended address, classifying letters by arranging them based on their importance and determining which officials should handle the letters by including a disposition sheet.

Currently, many agencies, both government and private sector, have implemented Information Technology in their administrative processes, whether based on desktop, web or mobile. No exception at the Sriwijaya State Polytechnic which is a Palembang College which has a commitment to be a superior and leading vocational education institution, of course it must be balanced with the implementation of its Information Technology in achieving this vision. Currently, State Polytechnic of Sriwijaya has implemented an information system in several of its business processes, for example the Academic Information System (SISAK), which contains all academic activities such as lecture attendance, monitoring lecturers teaching and student assessments.

However, the problem is in the administrative process, especially letter disposition. In its implementation, Sriwijaya State Polytechnic, letter disposition is still done manually in the sense that it has not been computerized. In the process of filing letters and disposing of letters, data recording still uses manual recording or recording using a spreadsheet application (Microsoft Excel). This can lead to potential problems such as delays in executing letters due to lost letters, scattered letters, and leaders not in place for a long period of time. So that digitization is needed in tracking letter disposition, which stores all letter data into a database that can be accessed directly by the leadership. The mail disposition tracking process is made on a web-based basis that can be run on the Android platform via Android Webview. In the system created allows several users to see the position of the letter has been received by any party, which makes it easier for users with an interest in the letter to know whether the letter has been processed or not. So the hope is that this application can improve efficiency in the letter dissecting process 


\subsection{Aim and Goal}

Based on the Introduction described above, the purpose of this study are:

1. Creating a letter disposition monitoring system that makes it easier for the leadership of the State Polytechnic of Sriwijaya to monitor letters

2. Simplify the letter disposition process by implementing a computerized system based on the Android webview

3. Make it easier to document computerized letter dispositions in the Sriwijaya State Polytechnic environment

\subsection{The Scope}

The scope of this research includes:

1. This research focuses on monitoring the disposition of letters from and to the director in the State Polytechnic of Sriwijaya's environment

2. System design and data modeling are carried out by structured design with context diagram modeling, data flow diagrams, entity relationship diagrams

3. System implementation using Sublime Text Editor tools, Android WebView, MySQL database, web programming languages (PHP, HTML, CSS, and Javascript)

\section{LITERATURE REVIEW}

\subsection{Disposition}

Disposition is a written instruction regarding follow-up management of the letter along with the disposition sheet delivered by the courier to the designated agency or bureau, then if necessary the authorized official can carry out further disposition to his subordinates until the letter reaches the executor for further action.[1]

\subsection{Web Based Programming}

PHP is used as the core programming language for the server of the system being created. PreProcessor (PHP) is usually a script that integrates with HTML tags that are executed on the server and developed for dynamic web creation [2]. Dynamic web is a web where the data contained in it can be changed or updated at any time depending on the needs [3]. The characteristic of a dynamic web is that it can interact with service users or visitors to the information displayed from the database stored on the web server. PHP is maintenance for making a website easily. PHP is also a server side scripting language that is embedded in HTML.

MySQL is a derivative of one of the main concepts in existing databases, namely SQL (Structured Query Language). SQL is a concept of database operations, especially for selecting or selecting and entering data, which allows data operations to be done easily automatically [4].

\subsection{Data Flow Diagram}

Data Flow Diagram (DFD) is a graphic representation that depicts the flow of information and information transformation applied as data flowing from input and output[5]. The design stages using the Data Flow Diagram, namely:

1. Make DFD Level 0 or often called Context Diagram

DFD Level 0 describes the system to be created as a single entity that interacts with other people and systems. DFD Level 0 is used to describe the interaction between the system to be developed with external entities.

2. Creating DFD Level 1

DFD Level 1 is used to describe the modules in the system to be developed. DFD Level 1 is the result of the DFD Level 0 breakdown that was previously created.

3. Creating DFD Level 2

Modules in DFD Level 1 can be broken down into DFD Level 2. Which modules should be broken down in more detail depends on the details of the module. If the module is sufficiently detailed and locked, then the module does not need to be broken down again. For a system, the number of DFD Level 2 is the same as the number of modules in DFD Level 1 that are broken down

4. Make DFD Level 3 and so on

DFD Level 3,4,5, and so on is a breakdown of modules on DFD Level above it. Breakdown at level 3,4,5, and so on, the rules are exactly the same as DFD Level 1 or 2.

\subsection{Webview Android Based Application}

The Android System WebView application is a system component or extension that is supported by chrome, with the Android System Webview on Android phones, we can open website pages directly from thirdparty applications without having to open a browser.[8] The point is how to make user friendly in user interface and user experience [7]. The mobile apps is the part of human activity that could not be separated as daily routine [11]

On operating systems 4.4 and above, Android System WebView uses the open source base of Google Chrome (which uses the Google Blink engine) [9]. While on the Android 5.0 operating system, Android System WebView is a separate application and allows it to be updated via Google Play without requiring a firmware update first [10]. 


\section{RESEARCH METHOD}

The method of this research based on System Development Life Cycle (SDLC) as followed by this figure:

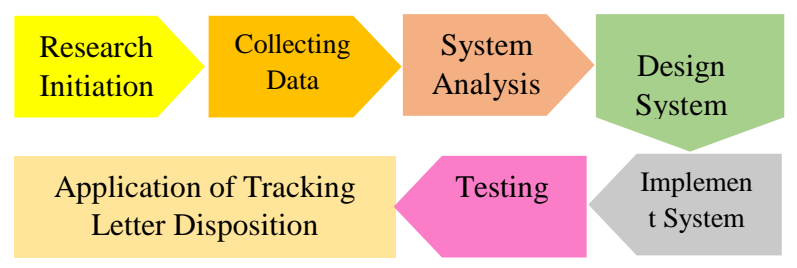

Figure 1. Research Method

In conducting system development, here is the explanation of research method as illustrateg in the figure above:

\section{Research Initiation}

It is the initial stage, where at this stage it is determined what is the background of the research, proposing and formulating the problem, and the purpose of the problem. The research was conducted at the State Polytechnic of Sriwijaya with a focus on making a mail disposition tracking application.

\section{Data Collection}

Data collection was carried out in 3 ways are observation, interview and document study

\section{A. Observation}

Researchers made direct observations on the process of disposing letters from and to leaders in the Sriwijaya State Polytechnic Environment. In this case, the researcher also saw how the administration was carried out by the administration

B. Interview

After making direct observations, the researcher conducted interviews with related parties in the letter disposition process. Interviews were conducted to explore further problems, while the parties involved in the interview were administrative staff

C. Document Study

Document study is carried out by looking at what documents are needed in the dissemination of letters in the State Polytechnic of Sriwijaya such as SOPs, recapitulation of incoming letters, recapitulation of outgoing letters.

\section{System Analysis}

System analysis looks at several aspects, namely problem analysis, running system analysis and analysis of the proposed system. In problem analysis, it is done by looking at the problems and how to solve these problems. The current system analysis looks at how the existing system is, how is the process of manually disposing of letters. Analysis of the current system is represented by a flowchart or workflow diagram. Meanwhile, the Proposed System Analysis looks at 2 aspects, those are Functional Analysis and Non-Functional Analysis.

\section{System Design}

System design uses structured design using Context Diagrams, Data Flow Diagrams (DFD), Entity Relationship Diagrams (ERD), Database Design, User Interface Display Design, pseudocode and Data Dictionary

\section{System Implementation}

In this stage is coding where the results of the design in the previous stage are implemented in the programming language. Tools and programming languages in system implementation are PHP, HTML, CSS, Javascript, MySQL and Sublime Text Editor

\section{Testing Program}

In this stage the program testing uses Blackbox Testing which tests the functional aspects of the program. Program testing is done by creating a test scenario and then testing it on the system to see whether the scenario is successful or not.

\section{RESULT AND DISCUSSION \\ 4.1. Data Flow Diagram}

Data flow diagrams (DFD) are a description of the data flow from the process of originating the data to the results of the data. The following is a Level 0 Data Flow Diagram (DFD) or Context Diagram:

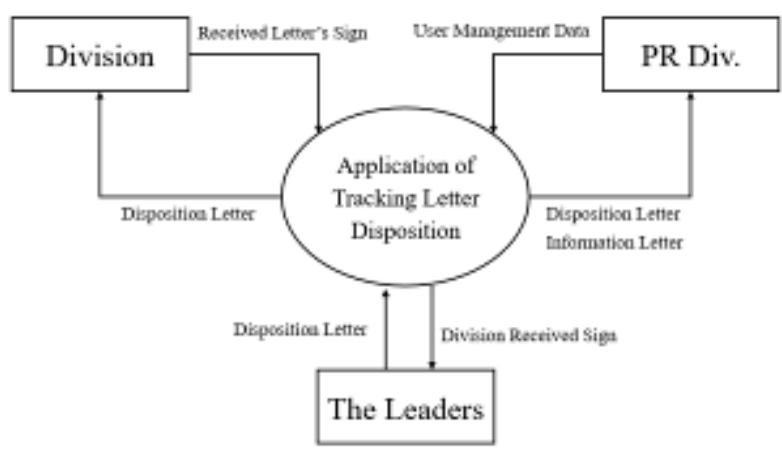

Figure 2. Context Diagram

In Figure 2 above shows 3 entities that related to the system, they are Division, Public Relation Division and The Leaders (The Executives). The entities have their data flow that from/to the system, such as Division gives data flow "Received Letter's Sign" to the system and get "Disposition Letter" from the system. Meanwhile The Leaders entity gets Data Flow "Division Received Sign" 
and gives "Disposition Letter" to the system. After determining the entities that related to the system, we have to breakdown based on process in detail. Figure 3 show Data Flow Diagram Level 1 that breakdown context diagram into some parts of system process :

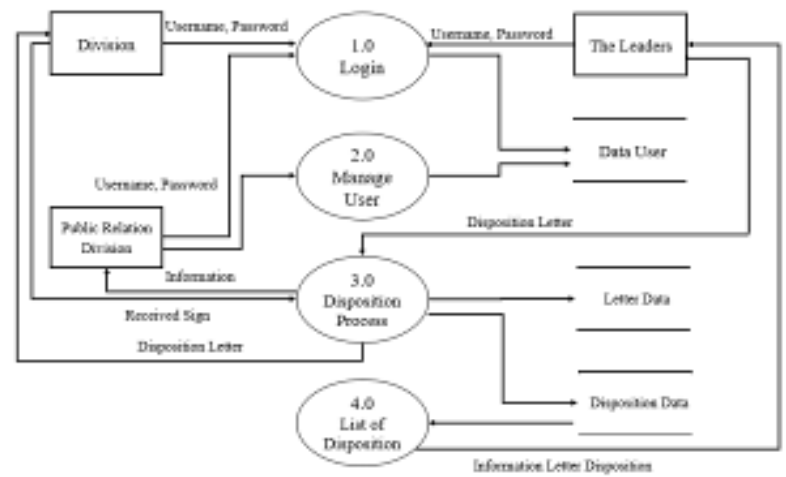

Figure 3. Data Flow Diagram Level 1

On Figure 3 defined by 4 main process on the system, they are Login, Manage User, Disposition Process and List of Disposition. Besides there are 3 data stored that included to the system. These are Data User, Letter Data and Disposition Data.

\subsection{Entity Relationship Diagram}

ERD is the modelling tools that describe the relation between entities in the system, here is the ERD below:

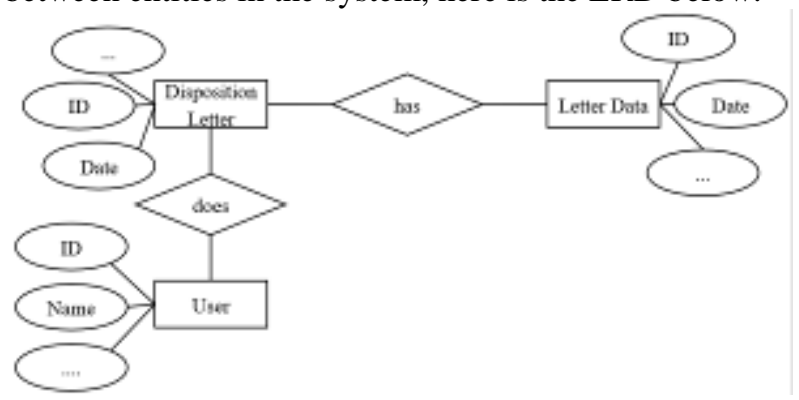

Figure 4. Entity Relationship Diagram

ERD show the relation for each data store that described on Data Flow Diagram Levelled before. This will be foundation for designing the database to the next stage. On figure 4 the relation defined by 2 relationship for 3 data, which are User. Disposition Letter and Letter Data.

\subsection{Database Design}

Based on ERD that describe above, the database design defined by 3 tables. Here is the detail for each tables:
Table 1. Table "Data Penerima"

\begin{tabular}{|c|c|c|c|}
\hline Field & Type & Length & Desc \\
\hline id_penerima & int & 11 & Primary key \\
\hline id_surat & int & 11 & \\
\hline nip & varchar & 20 & \\
\hline waktu_terima & varchar & 30 & \\
\hline
\end{tabular}

Table 2. Table "Data Pengguna"

\begin{tabular}{|c|c|c|c|}
\hline Field & Type & Length & Desc \\
\hline nip & varchar & 20 & Primary key \\
\hline password & varchar & 60 & \\
\hline nama & varchar & 30 & \\
\hline akses & varchar & 30 & \\
\hline
\end{tabular}

Table 3. Table "Data Surat"

\begin{tabular}{|c|c|c|c|}
\hline Field & Type & Length & Desc \\
\hline id_surat & int & 11 & Primary key \\
\hline no_surat & varchar & 10 & \\
\hline tanggal & date & - & \\
\hline jenis & enum & - & \\
\hline hal & varchar & 100 & \\
\hline dari & varchar & 30 & \\
\hline kepada & varchar & 30 & \\
\hline sifat & varchar & 30 & \\
\hline waktu & timestamp & - & \\
\hline dokumen & varchar & 255 & \\
\hline isi_disposisi & text & - & \\
\hline tanggapan & text & - & \\
\hline
\end{tabular}

\subsection{User Interface Design}

User interface (UI) design could be designed for making easier the programmer implement the design system. We can add the layout component in UI design. Here are the UI design below:

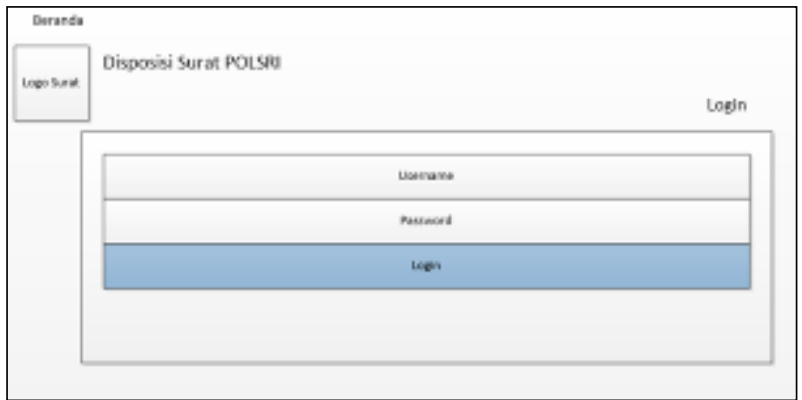

Figure 5. Login UI Design 
The login design is a page that functions to check access, this system can be accessed by leaders, public relations, and divisions.

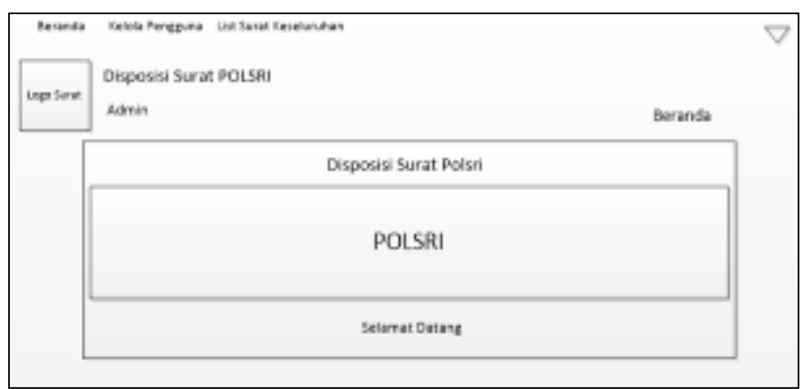

Figure 6. Main Menu UI Design

The main admin design is the front page of the application which provides various menu options for the admin to input users and view the entire mail list.

\begin{tabular}{|c|c|c|c|}
\hline Garking & rest 5m: Mnir : 2met & 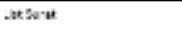 & \\
\hline \multirow{2}{*}{$\log 6 \pi$} & Dsppess| S.rnt FoLspI & & \\
\hline & Himes & & Berande \\
\hline & \multicolumn{3}{|c|}{ Okłpaski Surat Polsń } \\
\hline & \multicolumn{3}{|c|}{ POLSRI } \\
\hline & \multicolumn{3}{|c|}{ Sedura: Daiay } \\
\hline
\end{tabular}

Figure 7. Public Relation (Humas) Menu UI Design

The Public Relation (Humas) design is the front page of the application which provides various menu options for Humas to input users and view the entire mail list.

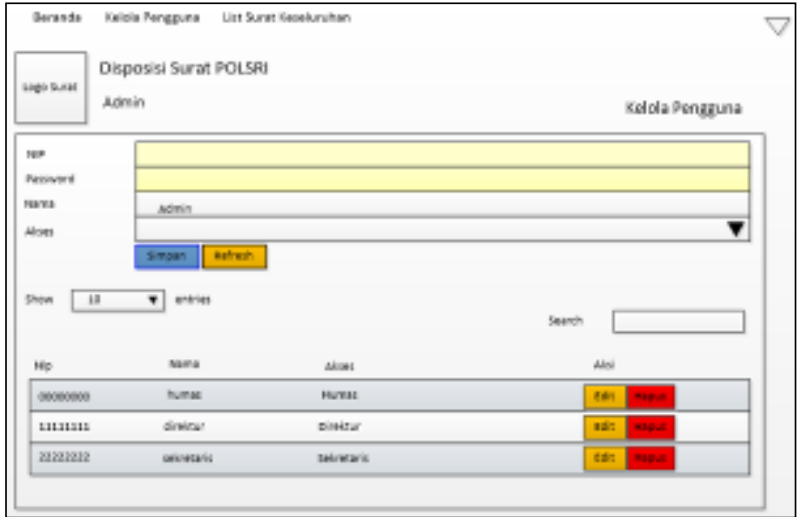

Figure 8. Admin user management Design

The design of the user management page contains content that contains the system user data form. User data form consists of NIP, password, name, and access. On the manage user page, there are save, refresh, edit, and delete buttons. Manage users page can only be accessed by admin

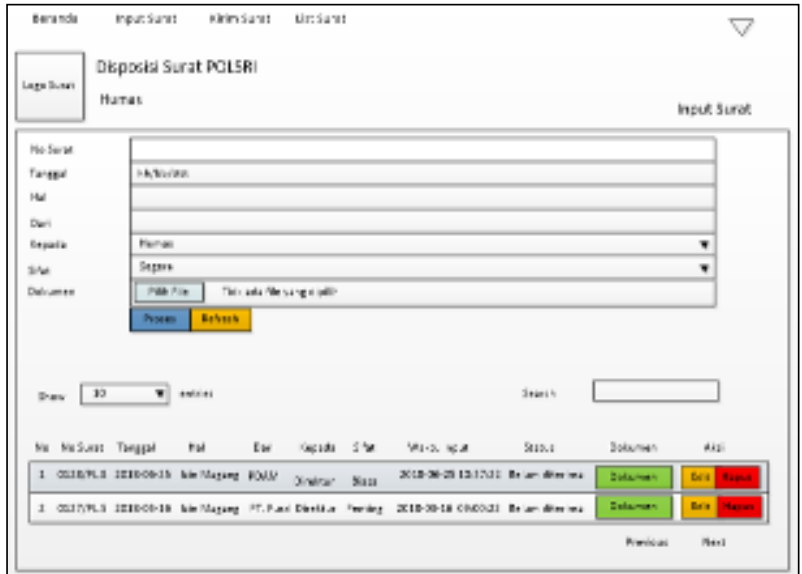

Figure 9. Input Data for Humas

The design of the letter input page contains content containing the letter data form from outside the Sriwijaya State Polytechnic. The letter input data form consists of letter number, date, letter case, from, to, nature of the letter, and documents. This document is a letter that has been scanned if the recipient of the letter is outside the Sriwijaya State Polytechnic. On this letter input page there are buttons for the process, refresh, edit, delete, select file. The file select button is a letter that has been scanned with a jpg or PDF type. This letter input page can only be accessed by public relations.

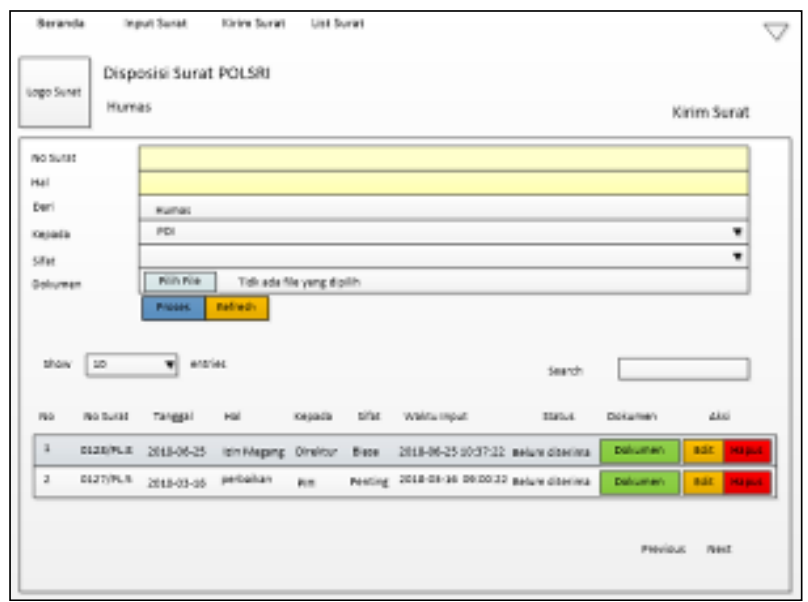

Figure 10. Sending Letter Form Design

The design of the sending letter page contains content containing the letter data form for other users. The data form for sending letters consists of letter number, letter case, from, to, nature of the letter, and documents. This document is a letter that has been scanned if the recipient of the letter is outside the Sriwijaya State Polytechnic. On the input page of this letter there are buttons for the process, refresh, edit, delete, select file. The file select button is a letter that has been scanned with a jpg or PDF type. 


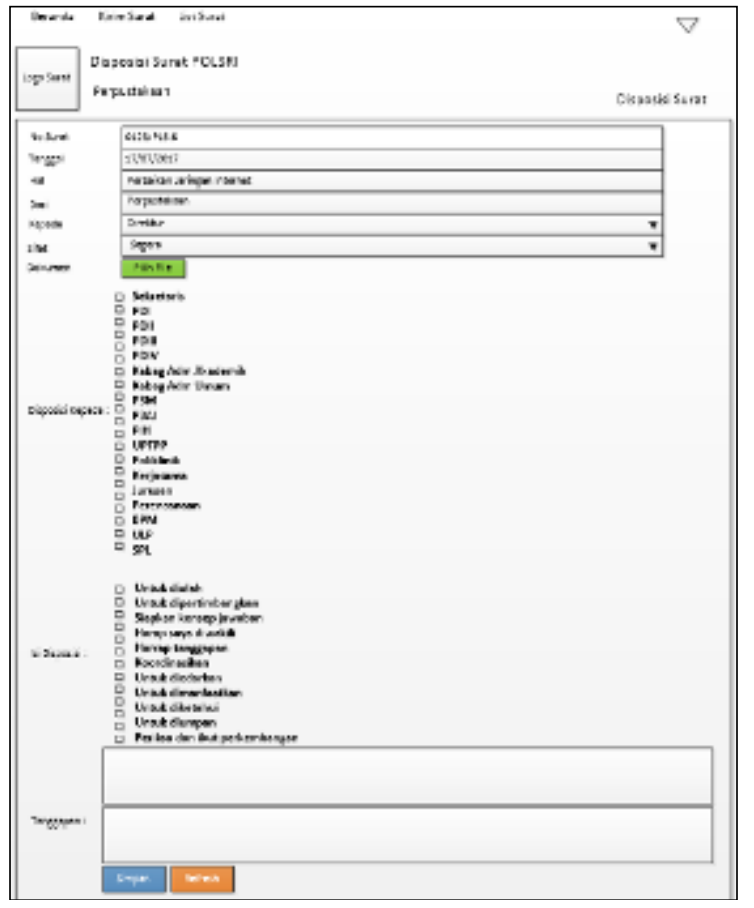

Figure 11. Disposition Form Design

The design of the letter list page contains content that contains a list of incoming mail for the user. The list consists of letter number, letter case, from, to, and date of input of the letter. There are 5 buttons on the letter list consisting of documents, dispositions, you receive, received by the secretary and dispositions.

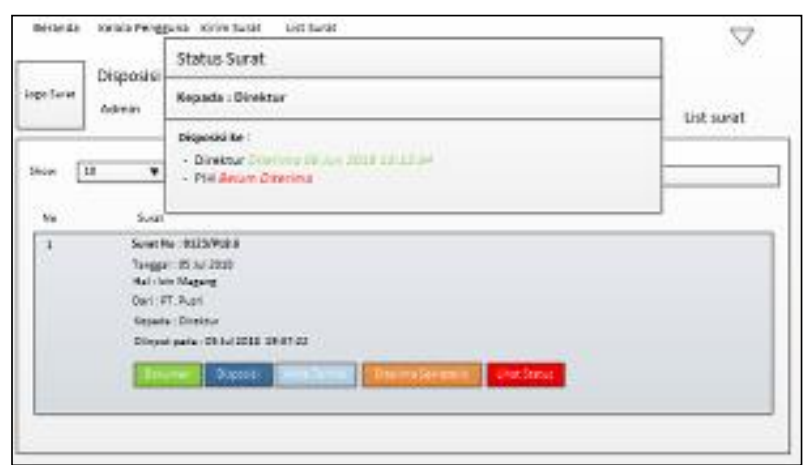

Figure 12. Letter Status Design

\subsection{Implementation System}

After designing the UI, the next stage is implementation the system by coding based on UI design and technically aspect such as pseudocode, database design, process figured by Context Diagram and Data Flow Diagram. Here is the screenshot of application that has been built:

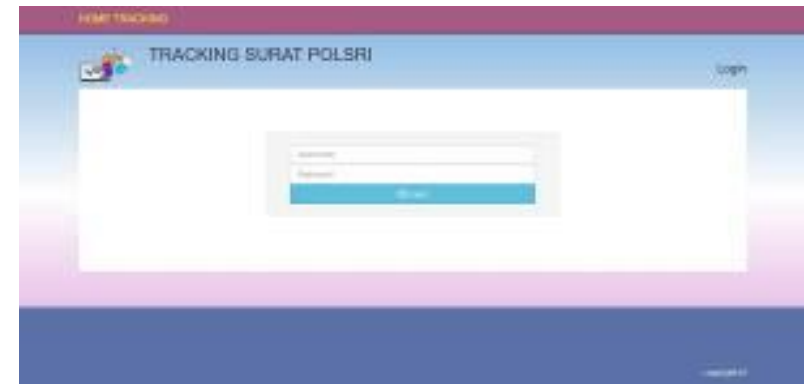

Figure 13. Login Form

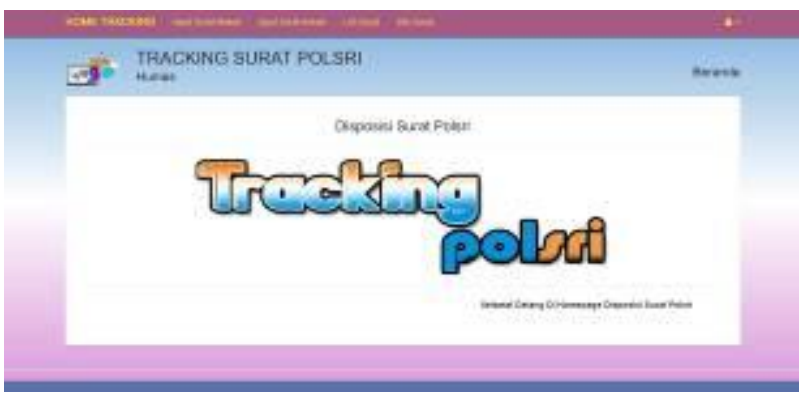

Figure 14. Main Menu Form

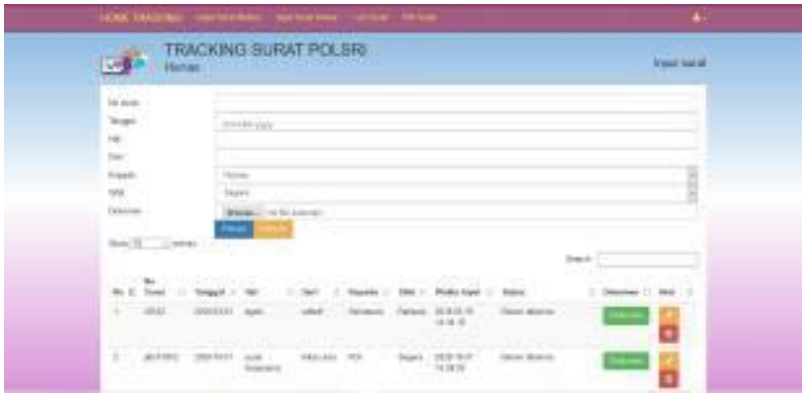

Figure 15. Disposition Process Form

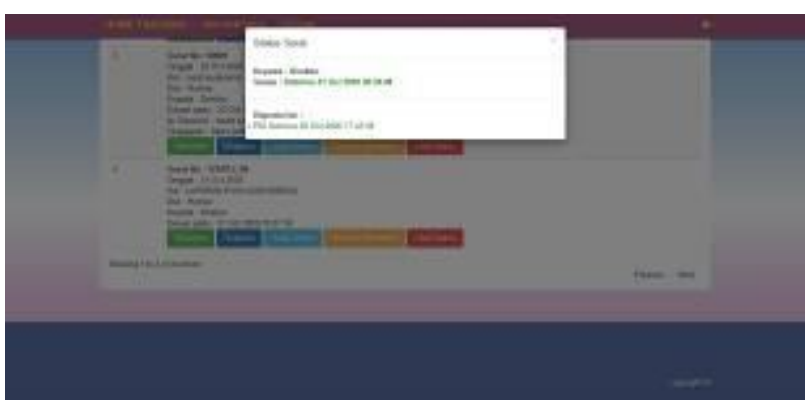

Figure 16. Information Status Disposition Form 


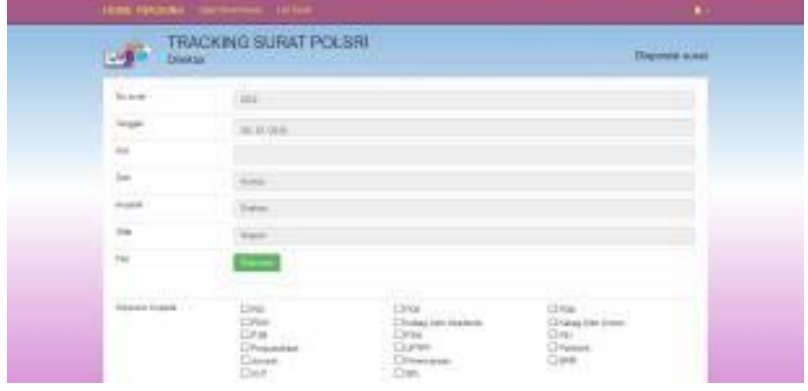

Figure 17. Input Letter Form

\subsection{Blackbox Testing}

The testing product using Blackbox testing approach where user is given scenarios in using the application. User check it out and write down OK if the system running well based on the scenario given. Here is the result of blackbox testing below:

Table 4. Blackbox Testing Result

\begin{tabular}{|l|l|l|}
\hline \multicolumn{1}{|c|}{$\begin{array}{c}\text { Feature } \\
\text { Tested }\end{array}$} & \multicolumn{1}{|c|}{$\begin{array}{c}\text { The } \\
\text { Result }\end{array}$} \\
\hline Login & Input username and Password & Accepted \\
\hline $\begin{array}{l}\text { User } \\
\text { Manage } \\
\text { ment }\end{array}$ & $\begin{array}{l}\text { Add, edit, delete, view the } \\
\text { user data }\end{array}$ & Accepted \\
\hline $\begin{array}{l}\text { Letter } \\
\text { Sending }\end{array}$ & $\begin{array}{l}\text { Input Letter data that will send } \\
\text { to other user }\end{array}$ & Accepted \\
\hline $\begin{array}{l}\text { View } \\
\text { Status }\end{array}$ & $\begin{array}{l}\text { Showing the status for the } \\
\text { receiver }\end{array}$ & Accepted \\
\hline $\begin{array}{l}\text { Letter } \\
\text { Disposition }\end{array}$ & $\begin{array}{l}\text { Doing the disposition to the } \\
\text { chosen user }\end{array}$ & Accepted \\
\hline Letter List & $\begin{array}{l}\text { Showing the list of letter that } \\
\text { has been disposed to other } \\
\text { user }\end{array}$ & Accepted \\
\hline
\end{tabular}

\section{CONCLUSION}

Based on the results and discussions that have been stated in the previous chapters, in general the author can conclude the following:

1. The monitoring system for the disposition of the executive letter of the Sriwijaya State Polytechnic is used to provide information about the flow of the director disposition letter so that it can be viewed on web and mobile.

2. This system is built using web tools and applies the fast method as a way to build the system.

\section{ACKNOWLEDGMENTS}

The acknowledgement of the research is purposed to State Polytechnic of Sriwijaya which has funded the research. Also to Public Relation division (Humas) which has given information and data during this research.

\section{REFERENCES}

[1] Aji, Sapto., Migunani., Fitro Nur Hakim. (2014). Rancang Bangun Sistem Informasi Disposisi Surat Berbasis Web (Studi Kasus Kementerian Pekerjaan Umum). STMIK provinsi Semarang.

[2] Sunoto, Imam. (2015). Perancangan Sistem Informasi Administrasi Akademik Berbasis Web. Universitas Indraprasta PGRI.

[3] Sukamto, Rosa A dan M. Shalaludin. (2013). Rekayasa Perangkat Lunak. Informatika: Bandung.

[4] Pratiwi, Sri Ambar., I Made Sukarsa,. I Ketut Adi Purnawan. (2014). Rancang Bangun Aplikasi Sistem Pemesanan Bunga Berbasis Android. Universitas Udayana.

[5] Fitriyani, Fifit. (2017). Penerapan Standars Operating Procedures (SOP) Pada Pelayanan Sirkulasi di Perpustakaan Fakultas Hukum UPN Veteran Jakarta. Universitas Islam Negeri Syarif Hidayatullah.

[6] Widiastuti, Nelly Indriani., Rani Susanto. (2014). Kajian Sistem Monitoring Dokumen Akreditasi Teknik Informatika Unikom. Universitas Komputer Indonesia.

[7] Isa, I. G. T. (2018). Kansei Engineering Approach in Software Interface Design. Journal of Science Innovare, 1(01), 22-26.

[8] H. Purnaweni and Riwayatiningsih, "Pemanfaatan Sistem Informasi Geografi dalam Pengembangan Pariwisata Geographic Information System Utilization in Tourism Development," Proceeding Biol. Educ. Conf., vol. 14, pp. 154-161, 2017.

[9] Triwibowo, Dodi., Rinta Kridalukmana, Kurniawan Teguh Martono. (2015). Pembuatan Aplikasi Terintegrasi, Pendataan Barang di Gudang Berbasis Android. Universitas Diponegoro.

[10] Pratiwi, Sri Ambar., I Made Sukarsa,. I Ketut Adi Purnawan. (2014). Rancang Bangun Aplikasi Sistem Pemesanan Bunga Berbasis Android. Universitas Udayana.

[11] Ma, L., Gu, L., \& Wang, J. (2014). Research and development of mobile application for android platform. International Journal of Multimedia and Ubiquitous Engineering, 9(4), 187-198. 